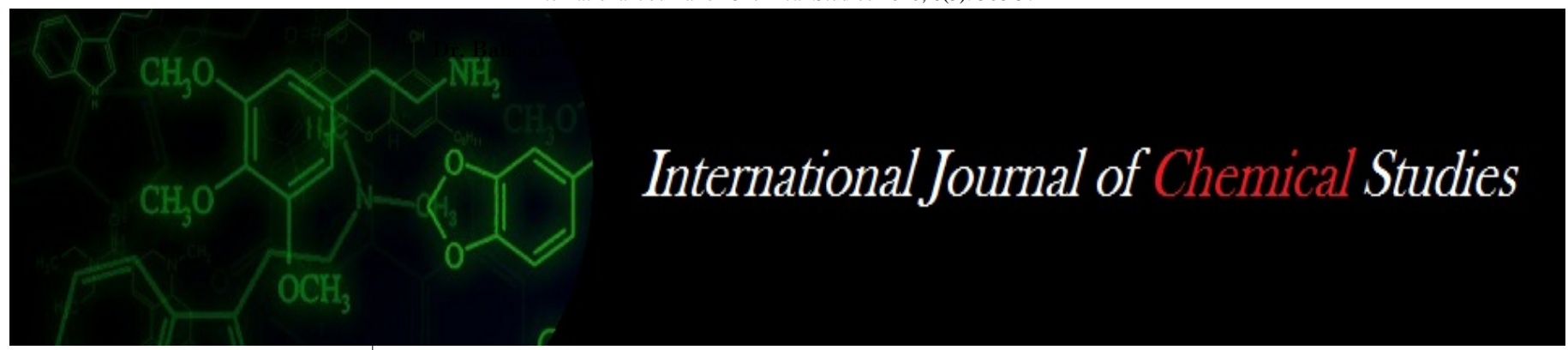

P-ISSN: 2349-8528

E-ISSN: 2321-4902

www.chemijournal.com

IJCS 2020; 8(3): 568-571

(C) 2020 IJCS

Received: 13-03-2020

Accepted: 14-04-2020

Ashok Pandit

Regional Research Station

Agwanpur, Sahrasa, Bihar, India.

\section{D.K. Dwivedi}

Department of Agronomy, Dr. Rajendra Prasad Central Agricultural University, Pusa, Samastipur, Bihar, India.

Anup Kumar Choubey

KVK, Aurangabad, Bihar, India.

Sweeti Kumari

KVK, Katihar, Bihar, India.

\section{R.K Raj}

Department of Agronomy,

Dr. Rajendra Prasad Central

Agricultural University, Pusa,

Samastipur, Bihar, India.

Gautam Kumar Goit

J.S. University, Shikohabad,

Kanthari, Uttar Pradesh, India.

\section{Effect of integrated nutrient management on yield and nutrient uptake of potato (Solanum tuberosum L.)}

\author{
Ashok Pandit, D.K. Dwivedi, Anup Kumar Choubey, Sweeti Kumari and \\ R.K Raj and Gautam Kumar Goit
}

DOI: https://doi.org/10.22271/chemi.2020.v8.i3g.9270

\begin{abstract}
A field experiment was conducted during the Rabi season of the year 2017-18 on potato with variety Kufri Ashoka to test the recommended dose of fertilizers (RDF) levels (0, 50, 75, 100, 125, 150\%) with two organic manures (vermicompost $5 \mathrm{t} / \mathrm{ha}$ and mustard oil cake $2.5 \mathrm{t} / \mathrm{ha}$ ) at research farm of Tirhut college of Agriculture Dholi, Muzaffarpur, Bihar. The experiment was carried out in randomized block design (RBD) with twelve treatments and replicated thrice. The soil of experimental plot was Entisols, sandy loam in texture under low available in $\mathrm{N}, \mathrm{P}$ and $\mathrm{K}$ with $\mathrm{pH}$ 8.3. Among the yield, nutrient uptake and available nutrient in soil after harvesting of potato were recorded higher with the application of treatment $\mathrm{T}_{11}-150 \% \mathrm{RDF}+5.0 \mathrm{t} / \mathrm{ha}$ vermicompost which was significantly superior over $\mathrm{T}_{1}$ - absolute control, $\mathrm{T}_{2}-100 \% \mathrm{RDF}, \mathrm{T}_{3}-50 \% \mathrm{RDF}+5.0$ t/ha vermicompost, $\mathrm{T}_{4}-50 \% \mathrm{RDF}+2.5 \mathrm{t} / \mathrm{ha}$ mustard oil cake, $\mathrm{T}_{5}-75 \% \mathrm{RDF}+5.0 \mathrm{t} / \mathrm{ha}$ vermicompost and $\mathrm{T}_{6}-75 \% \mathrm{RDF}+2.5 \mathrm{t} / \mathrm{ha}$ mustard oil cake but was statistically at par with treatments, $\mathrm{T}_{7}-100 \% \mathrm{RDF}+5.0 \mathrm{t} / \mathrm{ha}$ vermicompost, $\mathrm{T}_{8}-100 \% \mathrm{RDF}+2.5 \mathrm{t} / \mathrm{ha}$ mustard oil cake, $\mathrm{T}_{9}-125 \% \mathrm{RDF}+5.0 \mathrm{t} / \mathrm{ha}$ vermicompost, $\mathrm{T}_{10}-125 \% \mathrm{RDF}+2.5 \mathrm{t} / \mathrm{ha}$ mustard oil cake and $\mathrm{T}_{12}-150 \% \mathrm{RDF}+2.5 \mathrm{t} / \mathrm{ha}$ mustard oil cake.
\end{abstract}

Keywords: Recommended dose of fertilizers, vermicompost, mustard oil cake, yield, nutrient uptake, available nutrient in soil and Kufri Ashoka

\section{Introduction}

Potato (Solanum tuberosum L.) belongs to family Solanaceae. Peru-Bolivian region in the Andes (South America) is the centre of origin of potato and it has introduced to India in $17^{\text {th }}$ century by Portuguese traders or the Britishers and gradually become a commercial crop of all over India. Potato is one of the major vegetable crops of the India and occupies an important position among food crops and provides staple food stuff for millions of people of many part of the world. It is grown as a cash crop and capable in producing more food per unit area and time than cereals in short span of life. Potato (Solanum tuberosum L.) is a staple food crop of the world and it ranks next to rice, wheat and maize. It is highly amenable to adjustment and fits well in various cropping systems. Potato is well known for highest food value in the world. It has a high nutritive value, rich in contents like carbohydrates $20.6 \%$, protein $2.1 \%$, fat $0.3 \%$ and crude fiber $1.1 \%$. It is the cheapest source of nutrition for the rural mass hence it is called as “poor man's friend". The per capita consumption of potato in India is only $16 \mathrm{~kg}$ per annum but other countries the consumption of potato per capita is quite high thus the use of cereals should be substituted by potato in Indian scenario.

India is the second largest potato producing country in the world after China. In India, during 2015-16, potato is grown over an area of 2.11 million hectare with an annual production of 43.41 million tonnes with an average yield of $20.5 \mathrm{t} / \mathrm{ha}$. Almost $85 \%$ of total production comes from north India plain viz. Uttar Pradesh, West Bengal and Bihar. In world scenario, India has got second position after China with respect to production. Bihar is the third largest potato producer state of the country, occupying $5 \%$ area of total cultivated land i.e. 0.31 million hectare with a production of 6.34 million tonnes and productivity 19.88 t/ha (Horticultural statistics at a glance 2017). The productivity of potato can be increased and sustained by adoption of integrated nutrient management. Keeping this point in view the present
Corresponding Author: Ashok Pandit

Regional Research Station Agwanpur, Sahrasa, Bihar, India. 
investigation has been carried out.

The main constituents of potato cultivation are lack of quality seed, new cultivar and inappropriate doses of fertilizers (Kumar and Trehan, 2012) ${ }^{[9]}$. This high rate of dry matter production results in large amounts of nutrients removed per unit time, which generally most of the soils are not able to supply. Hence, nutrient application from external sources as fertilizers becomes essential. High yields can only be sustained through the application of optimal NPK doses in balanced proportion. Integrated use of sources of plant nutrients (chemical fertilizer and organic manures) is important not only for increasing crop productivity but also for improving soil fertility essential for sustaining the crop productivity.

\section{Materials and Methods}

The field experiment was laid out during Rabi season in year 2017-18 at the research farm of Tirhut College of Agriculture, Dholi (Muzaffarpur) which is situated on the southern bank of the river Burhi Gandak at an altitude of 52.18 meter above mean sea level and lies at $25^{\circ} .98^{\prime} \mathrm{N}$ latitude and $85^{\circ} .6^{\prime} \mathrm{E}$ longitude. The soil of experimental field was sandy-loam in reaction with $\mathrm{pH} 8.3$ and $\mathrm{EC} 0.43 \mathrm{~m}$. mhos $/ \mathrm{cm}$. It was moderately fertile being low in organic carbon $(0.45 \%)$, available nitrogen (220.4 $\mathrm{kg} \mathrm{N} \mathrm{ha}^{-1}$ ), phosphorous (17.8 kg $\mathrm{P}_{2} \mathrm{O}_{5} \mathrm{ha}^{-1}$ ) and potassium (120.02 kg K $\mathrm{O} \mathrm{ha}^{-1}$ ). The spacing row to row $60 \mathrm{~cm}$ and plant to plant $20 \mathrm{~cm}$ and cultivar 'Kufari Ashoka' was taken as a test crop.

Table 1: Initial chemical properties of experimental soil

\begin{tabular}{|c|c|c|c|}
\hline S.N. & Particulars & Values & Method adopted \\
\hline 1. & Organic carbon (\%) & 0.45 & Walkley and Black method (1934) \\
\hline 2. & $\mathrm{pH}(1: 2.5)$ & 8.30 & Buckman pH meter (Jackson, 1967) \\
\hline 3. & Electrical conductivity (m. mhos /cm at $25^{0} \mathrm{C}$ ) & 0.34 & Systronics electrical conductivity meter (Richards, 1954) \\
\hline 4. & Available Nitrogen (kg N /ha) & 220.40 & Alkaline permanganate method (Subbiah and Asija, 1956) \\
\hline 5. & Available Phosphorus ( $\left.\mathrm{kg} \mathrm{P}_{2} \mathrm{O}_{5} / \mathrm{ha}\right)$ & 17.88 & Olsen’s method (0.5 N NaHCO ${ }_{3}$ extractable) (Olsen et al., 1954) \\
\hline 6. & Available Potassium ( $\left.\mathrm{kg} \mathrm{K} \mathrm{K}_{2} \mathrm{O} / \mathrm{ha}\right)$ & 120.02 & Flame photometric method (Jackson, 1967) \\
\hline
\end{tabular}

Field experimental was laid out in Randomized Block Design with twelve treatments viz., $\mathrm{T}_{1}$ - absolute control, $\mathrm{T}_{2}-100 \%$ RDF, $\mathrm{T}_{3}-50 \% \mathrm{RDF}+5.0$ t/ha vermicompost, $\mathrm{T}_{4}-50 \% \mathrm{RDF}$ +2.5 t/ha mustard oil cake, $\mathrm{T}_{5}-75 \% \mathrm{RDF}+5.0 \mathrm{t} / \mathrm{ha}$ vermicompost, $\mathrm{T}_{6}-75 \% \mathrm{RDF}+2.5 \mathrm{t} /$ ha mustard oil cake, $\mathrm{T}_{7}$ $100 \% \mathrm{RDF}+5.0 \mathrm{t} / \mathrm{ha}$ vermicompost, $\mathrm{T}_{8}-100 \% \mathrm{RDF}+2.5$ t/ha mustard oil cake, $\mathrm{T}_{9}-125 \% \mathrm{RDF}+5.0 \mathrm{t} / \mathrm{ha}$ vermicompost, $\mathrm{T}_{10}-125 \% \mathrm{RDF}+2.5 \mathrm{t} / \mathrm{ha}$ mustard oil cake, $\mathrm{T}_{11}-150 \% \mathrm{RDF}+5.0 \mathrm{t} /$ ha vermicompost and $\mathrm{T}_{12}-150 \%$ $\mathrm{RDF}+2.5 \mathrm{t} / \mathrm{ha}$ mustard oil cake and replicated thrice.

\section{Description of experimental variety}

Kufri Ashoka - Kufri Ashoka developed through clonal selection from the segregating population of the hybrid EM/C-1021 x CP-1468. Central Potato Research Institute, Shimla, released this variety in 1996.

\section{Results and discussion \\ Tuber and vine yield}

Mean data given in (Table 2.) revealed that different treatments had significant effect on yield and vine yields. The highest tuber (276.15 q/ha) and vine yield (118.45 q/ha) was recorded with $150 \%$ recommended dose of fertilizer along with vermicompost which was significantly higher than other treatments but was at par with treatments $\mathrm{T}_{7} \mathrm{~T}_{8} \mathrm{~T}_{9} \mathrm{~T}_{10} \mathrm{~T}_{11}$ and $\mathrm{T}_{12}$. Higher yield obtained with application of higher dose of fertilizers (NPK) might be due to positive response of potato crop to the nutrients like nitrogen, phosphorus and potash. The beneficial response of organic manure to increase the crop yield might also be attributed to the availability of sufficient amounts of plant nutrients throughout the growth period and especially at critical growth periods of crops resulting its better uptake, plant vigour and superior yield attributes. These results are in conformity with the finding of Sarkar et al. (2011), Banjare (2012), Patel (2013) and Kumar et al. (2017).

\section{Nitrogen content in tuber and vine (\%) of potato}

Citation of the data regarding nitrogen content in tuber and vine revealed that potato crop grown through integrated use of organic and inorganic source of nutrients had shown a significant effect in Table 3. Among all treatment, $\mathrm{T}_{11}-150 \%$ $\mathrm{RDF}+5.0 \mathrm{t} / \mathrm{ha}$ vermicompost indicated maximum nitrogen content and minimum under treatment $\mathrm{T}_{1}$ - absolute control (0.89\%). Treatments, $\mathrm{T}_{7}-100 \% \mathrm{RDF}+5.0 \mathrm{t} / \mathrm{ha}$ vermicompost, $\mathrm{T}_{9}-125 \% \mathrm{RDF}+5.0 \mathrm{t} /$ ha vermicompost, $\mathrm{T}_{10}-$ $125 \% \mathrm{RDF}+2.5 \mathrm{t} /$ ha mustard oil cake and $\mathrm{T}_{12}-150 \% \mathrm{RDF}+$ $2.5 \mathrm{t} / \mathrm{ha}$ mustard oil cake was found statistically at par with $\mathrm{T}_{11}$ regarding nitrogen content in potato tuber and vine.

\section{Nitrogen uptake by tuber, vine and total uptake (kg/ha) of potato}

Perusal of mean data revealed that different treatments had significant effect on total nitrogen uptake by potato crop in Table 3. Among all treatments, $\mathrm{T}_{11}-150 \% \mathrm{RDF}+5.0 \mathrm{t} / \mathrm{ha}$ vermicompost recorded highest Nitrogen uptake by tuber, vine and total nitrogen uptake which was significantly superior over treatments $\mathrm{T}_{1}$ - absolute control, $\mathrm{T}_{2}-100 \%$ $\mathrm{RDF}, \mathrm{T}_{3}-50 \% \mathrm{RDF}+5.0 \mathrm{t} /$ ha vermicompost, $\mathrm{T}_{4}-50 \% \mathrm{RDF}$ +2.5 t/ha mustard oil cake, $\mathrm{T}_{5}-75 \% \mathrm{RDF}+5.0 \mathrm{t} / \mathrm{ha}$ vermicompost and $\mathrm{T}_{6}-75 \% \mathrm{RDF}+2.5 \mathrm{t} / \mathrm{ha}$ mustard oil cake and statistically at par to treatments, $\mathrm{T}_{7}-100 \% \mathrm{RDF}+5.0$ $\mathrm{t} /$ ha vermicompost, $\mathrm{T}_{8}-100 \% \mathrm{RDF}+2.5 \mathrm{t} / \mathrm{ha}$ mustard oil cake, $\mathrm{T}_{9}-125 \% \mathrm{RDF}+5.0$ t/ha vermicompost, $\mathrm{T}_{10}-125 \%$ $\mathrm{RDF}+2.5 \mathrm{t} /$ ha mustard oil cake and $\mathrm{T}_{12}-150 \% \mathrm{RDF}+2.5$ $\mathrm{t} /$ ha mustard oil cake. This might be due to narrow $\mathrm{C}$ : $\mathrm{N}$ ratio, continuous release of nutrients through the crop period and release of organic acids, which would have aided in the solubilization of minerals and change over from nonexchangeable to exchangeable form of nutrients which led to direct and early absorption of nitrogen, phosphorus and potassium resulting in better uptake of nutrients (Sasani et al., 2003). This result is conformity with the findings of Kumar et al. (2011) ${ }^{[14]}$ and Baishya (2009) ${ }^{[1]}$.

\section{Protien content in tuber (\%) on dry weight basis}

The data regarding protein content revealed that the maximum protein content content (12.69\%) recorded under treatment $\mathrm{T}_{11}-150 \% \mathrm{RDF}+5.0 \mathrm{t} / \mathrm{ha}$ vermicompost which was statistically at par with $\mathrm{T}_{7}-(12.38 \%), \mathrm{T}_{8}-(12.06 \%), \mathrm{T}_{9}-$ $125 \% \mathrm{RDF}+5.0 \mathrm{t} /$ ha vermicompost $(12.56 \%), \mathrm{T}_{10}-(12.31 \%)$ and $\mathrm{T}_{12}-(12.56 \%)$ and significantly superior over rest of the 
treatments. The minimum protein content (9.38) was estimated under treatment $\mathrm{T}_{1}$ - absolute control on dry weight basis. It might be due to increased involvement of nitrogen in accumulation of amino acid. Amino acid is an important constituent of protein thus increased protein content at higher dose of nitrogen applied. Thus result shows similarity with idea of Rai et al. (2004) ${ }^{[12]}$ and Chopra et al. (2006) ${ }^{[3]}$.

\section{Phosphorus content in tubers and vine (\%)}

The data presented in table shown the effect of different treatments on phosphorus content in tuber and vine clearly revealed that different treatments had significant effect on content. However, treatment $\mathrm{T}_{11}-150 \% \mathrm{RDF}+5.0 \mathrm{t} / \mathrm{ha}$ vermicompost was recorded maximum which was significantly superior to other treatments and statistically at par with treatment $T_{7}, T_{9}, T_{10}$, and $T_{12}$, while minimum phosphorus content was recorded under treatment $\mathrm{T}_{1}$ absolute control.

\section{Phosphorus uptake by tubers, vine and total uptake of Phosphorus (kg/ha) of potato}

Perusal of mean data revealed that different treatments had significant effect on total P- uptake by potato crop in Table 4. Among all treatment $\mathrm{T}_{11}-150 \% \mathrm{RDF}+5.0 \mathrm{t} / \mathrm{ha}$ vermicompost recorded the highest Phosphorus uptake by tubers, vine and total phosphorus uptake which was statistically at par with $\mathrm{T}_{7}-100 \% \mathrm{RDF}+5.0 \mathrm{t} / \mathrm{ha}$ vermicompost, $\mathrm{T}_{8}-100 \% \mathrm{RDF}+2.5 \mathrm{t} / \mathrm{ha}$ mustard oil cake, $\mathrm{T}_{9}$ - 125\% RDF + 5.0 t/ha vermicompost, $\mathrm{T}_{10}-125 \% \mathrm{RDF}+2.5$ t/ha mustard oil cake and $\mathrm{T}_{12}-150 \% \mathrm{RDF}+2.5 \mathrm{t} / \mathrm{ha}$ mustard oil cake and significantly superior over remaining treatments. The Phosphorus uptake by tubers, vine and total phosphorus uptake was obtained under treatment $\mathrm{T}_{1}$ - absolute control (without NPK and organic manures). Apart this, the increase in total uptake of $\mathrm{P}$ with application of organic manures might be due to improvement in inherent nutrient supplying capacity of soil, balanced supply of nutrients throughout the crop growth period, increased availability of nutrients and also by increasing nutrients efficiency (Kaminvar and Rajagopal, 1990). This result is conformity with the findings of Kumar and Singh (2016) ${ }^{[7]}$ and Kumar et al. (2008) ${ }^{[6]}$.

\section{Potassium content in tubers and vine (\%)}

The data presented in table shown the effect of different treatments on $\mathrm{K}$ - content in tuber and vine clearly revealed that different treatments had significant effect on content. However, treatment $\mathrm{T}_{11}-150 \% \mathrm{RDF}+5.0$ t/ha vermicompost recorded maximum potassium content in tuber and vine, which was significantly superior to other treatments while minimum was recorded on in control plot, regarding potassium content in potato dry tuber and vine.

\section{Potassium uptake by tubers, vine and total Potassium uptake (kg/ha) of potato}

Perusal of mean data revealed that different treatments had significant effect on Potassium uptake by tubers, vine and total Potassium uptake in Table 5. Among all treatment $\mathrm{T}_{11}$ $150 \% \mathrm{RDF}+5.0$ t/ha vermicompost recorded highest Potassium uptake by tubers, vine and total Potassium uptake which was significantly superior over remaining treatments and statistically at par to treatments, $\mathrm{T}_{7}-100 \% \mathrm{RDF}+5.0$ t/ha vermicompost, $\mathrm{T}_{8}-100 \% \mathrm{RDF}+2.5 \mathrm{t} / \mathrm{ha}$ mustard oil cake, $\mathrm{T}_{9}-125 \% \mathrm{RDF}+5.0 \mathrm{t} /$ ha vermicompost, $\mathrm{T}_{10}-125 \%$ $\mathrm{RDF}+2.5 \mathrm{t} /$ ha mustard oil cake and $\mathrm{T}_{12}-150 \% \mathrm{RDF}+2.5$ t/ha mustard oil cake, while minimum Potassium uptake by tubers, vine and total Potassium uptake was obtained under treatment $\mathrm{T}_{1}$ - absolute control (without NPK and organic manure). It might be due to the more availability of potassium by the mechanism and mineralization of organic compost and solubilisation of fixed potassium in the soil. This result is conformity with the findings of Kumar and Singh (2016) ${ }^{[7]}$ and Kumar et al. (2008) ${ }^{[6]}$.

Table 2: Effect of different treatments on fresh tuber and vine yield of potato $(\mathrm{q} / \mathrm{ha})$

\begin{tabular}{|c|c|c|c|}
\hline Treatments & $\begin{array}{c}\text { Fresh tuber yield } \\
(\mathbf{q} / \mathbf{h a})\end{array}$ & $\begin{array}{c}\text { Yield of vine } \\
\mathbf{( q / h a )}\end{array}$ & $\begin{array}{c}\text { Yield of biomass } \\
(\mathbf{q} / \mathbf{h a} \mathbf{)}\end{array}$ \\
\hline $\mathrm{T}_{1}$ & 111.28 & 72.20 & 183.47 \\
\hline $\mathrm{T}_{2}$ & 233.30 & 106.69 & 339.98 \\
\hline $\mathrm{T}_{3}$ & 210.24 & 100.68 & 310.92 \\
\hline $\mathrm{T}_{4}$ & 207.02 & 99.45 & 306.47 \\
\hline $\mathrm{T}_{5}$ & 237.23 & 106.48 & 343.72 \\
\hline $\mathrm{T}_{6}$ & 235.58 & 105.59 & 341.18 \\
\hline $\mathrm{T}_{7}$ & 262.00 & 115.96 & 377.96 \\
\hline $\mathrm{T}_{8}$ & 259.67 & 116.72 & 376.39 \\
\hline $\mathrm{T}_{9}$ & 272.45 & 117.26 & 389.71 \\
\hline $\mathrm{T}_{10}$ & 269.23 & 117.15 & 386.38 \\
\hline $\mathrm{T}_{11}$ & 276.15 & 118.45 & 394.66 \\
\hline $\mathrm{T}_{12}$ & 273.87 & 118.21 & 392.09 \\
\hline $\mathrm{S} \mathrm{Em}( \pm)$ & 8.24 & 3.48 & 12.37 \\
\hline $\mathrm{CD}(p=0.05)$ & 24.16 & 10.19 & 36.28 \\
\hline
\end{tabular}

Table 3: Effect of different treatments on protein content and N- content and uptake in potato

\begin{tabular}{|c|c|c|c|c|c|c|}
\hline Treatments & $\begin{array}{c}\text {-content in tuber } \\
(\mathbf{\%})\end{array}$ & $\begin{array}{c}\text { N-content in vine } \\
\mathbf{( \% )}\end{array}$ & $\begin{array}{c}\text { Protein content } \\
\mathbf{( \% )}\end{array}$ & $\begin{array}{c}\mathbf{N}-\text { uptake by tuber } \\
\mathbf{( k g} / \mathbf{h a})\end{array}$ & $\begin{array}{c}\text { N-uptake by vine } \\
\mathbf{( k g} / \mathbf{h a})\end{array}$ & $\begin{array}{c}\text { Total uptake } \\
\mathbf{( k g} / \mathbf{h a})\end{array}$ \\
\hline $\mathrm{T}_{1}$ & 1.50 & 0.89 & 9.38 & 33.43 & 8.04 & 41.47 \\
\hline $\mathrm{T}_{2}$ & 1.80 & 1.18 & 11.25 & 84.12 & 15.76 & 99.89 \\
\hline $\mathrm{T}_{3}$ & 1.69 & 1.05 & 10.56 & 71.18 & 13.24 & 84.41 \\
\hline $\mathrm{T}_{4}$ & 1.66 & 1.01 & 10.38 & 68.94 & 12.59 & 81.53 \\
\hline $\mathrm{T}_{5}$ & 1.78 & 1.16 & 11.13 & 84.66 & 15.48 & 100.13 \\
\hline $\mathrm{T}_{6}$ & 1.71 & 1.13 & 10.69 & 80.69 & 14.94 & 95.63 \\
\hline $\mathrm{T}_{7}$ & 1.98 & 1.26 & 12.38 & 103.96 & 18.30 & 122.26 \\
\hline $\mathrm{T}_{8}$ & 1.93 & 1.22 & 12.06 & 100.43 & 17.84 & 118.27 \\
\hline $\mathrm{T}_{9}$ & 2.01 & 1.32 & 12.56 & 109.77 & 19.39 & 129.17 \\
\hline $\mathrm{T}_{10}$ & 1.97 & 1.29 & 12.31 & 106.19 & 18.91 & 125.11 \\
\hline $\mathrm{T}_{11}$ & 2.03 & 1.35 & 12.69 & 112.28 & 20.02 & 132.30 \\
\hline $\mathrm{T}_{12}$ & 2.01 & 1.33 & 12.56 & 110.31 & 19.69 & 130.00 \\
\hline $\mathrm{S} \mathrm{Em}( \pm)$ & 0.06 & 0.04 & 0.37 & 5.77 & 1.04 & 6.81 \\
\hline $\mathrm{CD}(p=0.05)$ & 0.17 & 0.11 & 1.07 & 16.92 & 3.05 & 19.97 \\
\hline
\end{tabular}


Table 4: Effect of different treatments on P- content and uptake in potato

\begin{tabular}{|c|c|c|c|c|c|}
\hline Treatments & P-content in tuber (\%) & P-content in vine (\%) & P-uptake by tuber (kg/ha) & P-uptake by vine (kg/ha) & Total uptake (kg/ha) \\
\hline $\mathrm{T}_{1}$ & 0.31 & 0.25 & 6.91 & 2.26 & 9.17 \\
\hline $\mathrm{T}_{2}$ & 0.38 & 0.32 & 17.76 & 4.27 & 22.03 \\
\hline $\mathrm{T}_{3}$ & 0.34 & 0.29 & 14.32 & 3.66 & 17.97 \\
\hline $\mathrm{T}_{4}$ & 0.33 & 0.27 & 13.70 & 3.37 & 17.07 \\
\hline $\mathrm{T}_{5}$ & 0.37 & 0.32 & 17.60 & 4.27 & 21.87 \\
\hline $\mathrm{T}_{6}$ & 0.36 & 0.31 & 16.99 & 4.10 & 21.09 \\
\hline $\mathrm{T}_{7}$ & 0.40 & 0.34 & 21.00 & 4.94 & 25.94 \\
\hline $\mathrm{T}_{8}$ & 0.39 & 0.33 & 20.30 & 4.82 & 25.12 \\
\hline $\mathrm{T}_{9}$ & 0.42 & 0.36 & 22.94 & 5.13 & 28.23 \\
\hline $\mathrm{T}_{10}$ & 0.40 & 0.35 & 21.56 & 5.49 & 26.69 \\
\hline $\mathrm{T}_{11}$ & 0.43 & 0.37 & 23.78 & 5.33 & 29.27 \\
\hline $\mathrm{T}_{12}$ & 0.41 & 0.36 & 22.50 & 0.28 & 27.83 \\
\hline $\mathrm{S} \mathrm{Em}( \pm)$ & 0.01 & 0.01 & 1.20 & 0.83 & 1.47 \\
\hline $\mathrm{CD}(p=0.05)$ & 0.04 & 0.03 & 3.51 & & 4.31 \\
\hline
\end{tabular}

Table 5: Effect of different treatments on K- content and uptake in potato

\begin{tabular}{|c|c|c|c|c|c|}
\hline Treatments & K-content in tuber (\%) & K-content in vine (\%) & K-uptake by tuber (kg/ha) & K-uptake by vine (kg/ha) & Total uptake (kg/ha) \\
\hline $\mathrm{T}_{1}$ & 1.83 & 0.98 & 40.78 & 8.86 & 49.64 \\
\hline $\mathrm{T}_{2}$ & 2.16 & 1.16 & 100.95 & 15.50 & 116.44 \\
\hline $\mathrm{T}_{3}$ & 2.08 & 1.06 & 87.60 & 13.36 & 100.96 \\
\hline $\mathrm{T}_{4}$ & 2.04 & 1.04 & 84.72 & 12.97 & 97.69 \\
\hline $\mathrm{T}_{5}$ & 2.14 & 1.15 & 101.78 & 15.34 & 117.12 \\
\hline $\mathrm{T}_{6}$ & 2.10 & 1.13 & 99.10 & 14.94 & 114.03 \\
\hline $\mathrm{T}_{7}$ & 2.23 & 1.29 & 117.09 & 18.74 & 135.82 \\
\hline $\mathrm{T}_{8}$ & 2.20 & 1.27 & 114.48 & 18.57 & 133.05 \\
\hline $\mathrm{T}_{9}$ & 2.26 & 1.32 & 123.43 & 19.39 & 142.82 \\
\hline $\mathrm{T}_{10}$ & 2.24 & 1.29 & 120.75 & 18.91 & 139.66 \\
\hline $\mathrm{T}_{11}$ & 2.31 & 1.34 & 127.76 & 19.87 & 147.63 \\
\hline $\mathrm{T}_{12}$ & 2.28 & 1.33 & 125.12 & 19.69 & 1.05 \\
\hline $\mathrm{S} E \mathrm{E}( \pm)$ & 0.07 & 0.04 & 6.70 & 1.05 & 7.75 \\
\hline $\mathrm{CD}(p=0.05)$ & 0.20 & 0.11 & 19.65 & 3.08 & 2.73 \\
\hline
\end{tabular}

\section{Reference}

1. Baishya L.K. Response of potato varieties to organic and inorganic sources of nutrients Ph.D. Thesis, VisvaBharati, West Bengal, India, 2009, 99-102.

2. Banjare S. Study on the effect of different levels of nitrogen in the form of urea on potato production, M. Sc. (Ag.) Thesis IGKV, Raipur, 2012, 82-83.

3. Chopra S, Kanwar J.S, Samnotra R.K. Effect of different levels of nitrogen and potassium on growth, yield and biochemical composition of potatoes variety Kufri Jawahar Environment and Ecology. 2006; 24(2):268-271.

4. Horticultural Statistics at a Glance 2017 Database (Visit us at: www.agricoop.nic.in).

5. Kaminwar S.P, Rajagopal V. Fertilizer response and nutrient requirement of rainfed chilies in Andhra Pradesh Fertilizer News. 1993; 38:21-26.

6. Kumar M, Jadav M.K, Trehan S.P. Contributing of organic sources to potato nutrition at varying nitrogen levels, Global potato conference, New Delhi 9-12 Dec, 2008.

7. Kumar R, Singh N.D. Effect of inorganic and organic sources of nutrients on nutrient uptake, yield and economics of processing potato (Solonum tuberosum L.), International Journal of advanced research. 2016; 4(4):498-503.

8. Kumar M, Baishya L.K, Ghosh D.C, Gupta V.K. Yield and quality of potato (Solanum tuberosum) tubers as influenced by nutrient sources under rainfed condition of Meghalaya, Indian Journal of Agronomy. 2011; 56(3):260-266.
9. Kumar M, Trehan S.P. Influnence of potato cultivars and $\mathrm{N}$ levels on contribution of organic amendments to $\mathrm{N}$ nutrition Journal of Potato. 2012; 39(2):133-144.

10. Kumar P, Kumar A, Kumar N, Ahamad A, Verma M.K. Effect of integrated nutrient management on productivity and nutrients availability of potato, International Journal of Current Microbiology and Applied Sciences. 2017; 6(3):1429-1436.

11. Patel B. Effect of different levels of NPK on growth, development and yield of potato cv. Kufri Ashoka under chhattisgarh plain condition M.Sc. (Ag) Thesis IGKV, Raipur, 2013, 70-71.

12. Rai G.K, Verma M.M, Singh J. Effect of potassium and nitrogen on yield and quality of potato (Solanum tuberosum L.) tubers, Indian Journal of Agricultural Biochemistry. 2004; 17(1):45-46.

13. Sarkar A, Sarkar S, Zaman A. Growth and yield of potato as influenced by combination of organic manures and inorganic fertilizers Potato Journal. 2011; 38(1):78-80.

14. Sasani G.V, Patel C.K, Patel R.N, Patel N.H. Effect of levels of inorganic fertilizers with and without organic manures on yield of potato in North Gujarat, Journal of the Indian Potato Association. 2003; 30(1/2):77-78. 